\title{
Hydration Habits of Elite Field Futsal Players during Official Matches: Defenders and Forwards
}

\author{
J. V. García-Jiménez ${ }^{*}$ J. L. Yuste, J. J. García-Pellicer \\ Department of Physical Education, University of Murcia, 30100 Murcia, Spain \\ *Corresponding author: jvgjimenez@um.es
}

Received September 10, 2013; Revised January 03, 2014; Accepted January 10, 2014

\begin{abstract}
Futsal is a variant of soccer that is played on a smaller playing surface and mainly indoors. Futsal is played between two teams of five players, and unlimited substitutions per team are permitted. The purpose of this study has been to determine and to compare hydration habits and level of dehydration in elite futsal players during competition in relation to playing position. 4 defenders (DF) and 5 forwards (FW) were studied during 3 official matches $\left(22-26^{\circ} \mathrm{C}\right.$ and relative humidity $\left.32-42.33 \%\right)$ in the Spanish Futsal League (LNFS). Sweat loss was assessed through changes in body mass after correction for fluid intake (ad libitum) and urine loss. To analyze this data the statistics used are descriptive and not parametric. Mean sweat lost was higher in FW $(2458 \pm 670.91 \mathrm{~mL})$ than in DF $(1695.56 \pm 673.732 \mathrm{~mL})$. Fluid intake was higher in FW $(1700.36 \pm 857.12 \mathrm{~mL})$ than in DF $(1493.33 \pm 770.35 \mathrm{~mL})$. FW replaced less total fluid lost (63.64 $\pm 29.55 \%)$ than DF (79.53 $\pm 38.71 \%)$, so FW incurred a mean body mass deficit of $1.23 \pm 1.10 \%$, higher than DF $(0.59 \pm 1.10 \%)$. Even FW and DF were aware of the impact that dehydration has on performance. There is a significant correlation between game time and body weight loss (Spearman's Rho = $0.419, p \leq 0.05)$. There is significant difference in sweat lost in relation to playing position ( $p=0.020$; ES $=-1.311)$. We conclude that in these players, during official games, and independently of position, hydration status can be seen to maintain itself through regular substitutions and also the correct level of fluid intake. However, data allow for an individualisation of player hydration strategies, not taking exclusively into account playing position or game time.
\end{abstract}

Keywords: dehydration, fluid intake, playing position, competition, futsal

Cite This Article: J. V. García-Jiménez, J. L. Yuste, and J. J. García-Pellicer, "Hydration Habits of Elite Field Futsal Players during Official Matches: Defenders and Forwards.” American Journal of Sports Science and Medicine, vol. 2, no. 3 (2014): 88-92. doi: 10.12691/ajssm-2-3-4.

\section{Introduction}

Futsal is a variant of soccer that is played on a smaller playing surface $(40 \times 20 \mathrm{~m}$.) and mainly played indoors. Futsal is played between two teams of five players, one of whom is the goalkeeper, two defenders and two forwards. Unlimited substitutions per team are permitted. It is an intermittent high intensity sport, where the main energy pathway is the anaerobic metabolism [35,36].

To avoid a reduction in performance during games, players must ingest enough fluid to match their sweat loss [1-6]. Dehydration occurs when fluid loss by sweating is higher than fluid intake $[7,8]$, and it is a limiting factor for mental and physical performance during sport and physical activity [9-17].

A simple way to determine the level of dehydration achieved in futsal players is to weigh the athlete before and after performing the exercise, as the average loss of water through respiration in activity lasting less than 3 hours is barely significant compared to the loss through sweating [18]. The use of pre- to post exercise change in body mass provides a estimation of total fluid loss due to sweating $[3,5,16,18]$. Therefore, measurement of body weight changes is a simple, non-invasive and valid approach to estimate hydration changes in team sports, by calculating the difference in body weight pre- and post exercise [15,18,19,20,21].

A body water deficit greater than $2 \%$ of body weight marks the level of dehydration that can adversely affect physical performance $[10,12,13,14,15,16,19,22]$, and to reduce athlete's cognitive function as perceptual discrimination or reaction time $[10,15,22,23,24,25]$. This data is particularly relevant to our study because the performance of a futsal player will depend on both their physical condition and cognitive abilities to make right decisions in the shortest time.

Our investigation has studied elite futsal players during official games. The team analyzed is considered one of the best in the world, and the analysis of its players provides valuable information about futsal hydration habits during real competition. In similar articles published by studying first-level players, researchers are required to simulate competitive situations during training sessions $[1,4,26,27,28,29]$.

The aim of this study has been to determine and to compare the water balance and level of dehydration in elite futsal players in relation to playing position during three official matches, through the measurement of weight loss, urine loss and total fluid intake. 


\section{Materials and Methods}

In team sports, individual differences such as body weight, genetic predisposition or heat acclimatization state $[15,17,25,29,30]$, can affect sweat rates of players. It is recommended that players should monitor body weight changes during training/competition to estimate their sweat lost [15]. In addition, hydration level of players can vary considerably depending on their specific position, due to differences in intensity and duration of exercise performed during a match $[1,3,31,32]$. For this reason, our work has focused on determining and comparing results in variables sweat lost, fluid intake and body weight lost between elite futsal field players (defenders and forwards).

\subsection{Participants}

9 male futsal players (4 defenders and 5 forwards), from the first team squad of a professional club, were informed and gave their written consent to participate in this study, after the details had been explained to them. All players are professionals, with years of experience. Seven of whom are international with their national teams. The study was approved by the Institutional Review Board of the University of Murcia (Spain). Table 1 shows physical characteristics of players.

Table 1. Physical characteristics of players

\begin{tabular}{|c|c|c|c|c|}
\multicolumn{1}{c}{ Table 1. Physical characteristics of players } \\
\begin{tabular}{|c|c|c|c|} 
Playing \\
position
\end{tabular} & \multicolumn{2}{|c|}{ Defenders $(\mathrm{n}=4)$} & \multicolumn{2}{c|}{ Forwards $(\mathrm{n}=5)$} \\
\hline Variable & Mean \pm SD & Range & Mean \pm SD & Range \\
\hline $\begin{array}{c}\text { Age } \\
\text { (years) }\end{array}$ & $29.3 \pm 5.2$ & $(22-33)$ & $26.5 \pm 2.46$ & $(24-30)$ \\
\hline $\begin{array}{c}\text { Height } \\
\text { (cm.) }\end{array}$ & $176.5 \pm 7.3$ & $(169-185)$ & $178 \pm 9$ & $(169-192)$ \\
\hline $\begin{array}{c}\text { Body } \\
\text { mass } \\
\text { (kg.) }\end{array}$ & $73.2 \pm 5.5$ & $(69-85)$ & $\begin{array}{c}78.24 \pm \\
6.99\end{array}$ & $\begin{array}{c}(67.3- \\
84.3)\end{array}$ \\
\hline
\end{tabular}

Due to the difficulty to study other teams in the same level to get a representative sample, the sample selection was done using non-probability sampling, having performed the selection for convenience. Therefore, and because the sample is not representative, we can not infer the results of this research to other futsal teams.

Data were collected during three official matches in the Spanish Futsal League (LNFS), corresponding to gameweeks 25,27 and 29 (Table 2).

Table 2. Timing and climate conditions of matches*

\begin{tabular}{|c|c|c|c|}
\hline Gameweek & Time & Temperature $\left({ }^{\circ} \mathrm{C}\right)$ & $\begin{array}{c}\text { Relative } \\
\text { Humidity (\%) }\end{array}$ \\
\hline 25 & 18 ’30h. & 22 & 40 \\
\hline 27 & $13^{\prime} 45 \mathrm{~h}$. & 26 & 32 \\
\hline 29 & 18 '30h. & 24.8 & 42.33 \\
\hline
\end{tabular}

\subsection{Procedures}

A meteorological station OREGON SCIENTIFIC WMR-80 (Oregon ${ }^{\circledR}$, OR, USA), was used to record temperature and relative humidity, using the average value recorded since the start of warm-up to the final whistle.

To measure body weight we followed the protocol developed by the International Society for the Advancement of Kinanthropometry [33]. We used a scale TANITA BC-350 (Tanita ${ }^{\circledR}$, Illinois, USA) with 97\% reliability, accuracy $0.1 \mathrm{~kg}$. and a measurement range from 0 to $150 \mathrm{~kg}$. Players were weighed without clothing before the warm-up and after the match. Players were asked to micturate and defecate if necessary prior to the pre-warm-up measurement. Before weighing the players at the end of the match, perspiration was wiped of the player's legs, body and face with a towel, as indicated by Barbero et al. [20] in their study.

The percentage of weight loss was calculated using the following formula [34]:

$$
\begin{aligned}
& \text { \% Body weight lost : } \\
& {\left[\left(\begin{array}{l}
\text { Pre }- \text { match weight } \\
\text { - Post - match weight }
\end{array}\right) \text { / Pre - match weight }\right] \text { x } 100}
\end{aligned}
$$

Each player was provided with two individual $500 \mathrm{ml}$ drinks bottles. One of the bottles was filled with water from the brand "Aquadeus", and the other with the sports drink "Gatorade". The players had been consuming these two drinks throughout the season.

The volume of fluid introduced into each bottle was previously measured in a graduated test-tube with capacity of $1000 \mathrm{ml}$ and 1000:10 calibrated. The players were instructed to drink only from their own numbered bottles, just as they were told that in case they need more liquid they should advise the researcher so that he could fill the bottles. Fluid intake was therefore ad libitum. Once the match concluded, by subtracting the amount of liquid remaining in the player's bottle from the amount given to them, the total value for liquid consumed is yielded.

The volume of urine excreted by the players was measured since the warming-up to the end the match. After the first weighing of the players, and there after, each player had to urinate in a sterile and personal container, 1000:10 calibrated and prepared for his urine collection.

Total sweat loss was calculated using the following formula [2]:

Sweat loss $=\left(\begin{array}{l}\text { Pre }- \text { match weight }+ \text { Fluid intake } \\ - \text { Post }- \text { match weight }- \text { Urine excreted }\end{array}\right)$

Each player's game time was obtained by adding up the minutes played and warm-up time (standardized to 30 minutes). During the game, and because unlimited substitutions per team are permitted, the exact time when the player started and stopped playing was recorded. Finally, the time played was calculated by adding each player's action.

\subsection{Statistical Analysis}

A 2-way ANOVA was applied to determine reliability (ICCRs), and repeated measures ANOVA for the variables (body weight and fluid volume), obtaining ICC = 1 (95\% $\mathrm{CI} ; \mathrm{p} \leq 0,001)$. In addition, the design of this research is descriptive correlational. Data (game time, weight loss, fluid intake and excreted urine) are presented as mean, $\pm \mathrm{SD}$ and range, in relation to playing position (defenders or forwards). A non-parametric statistical analysis was applied, using Kruskal-Wallis test to determine differences between playing position of players. Effect size was also calculated using Cohen's d statistics. Spearman's Rho statistic has been applied to establish the correlation between game time and weight lost, with a 
statistical significance of $\mathrm{p} \leq 0.05$. The IBM SPSS 19.0 statistics package was used for the analysis.

\section{Results}

Table 3 shows that mean sweat lost was higher in forwards $(2458 \pm 670.91 \mathrm{~mL})$ than in defenders (1695.56 $\pm 673.732 \mathrm{~mL}$ ). Also mean fluid intake was higher in forwards $(1700.36 \pm 857.12 \mathrm{~mL})$ than in defenders $(1493.33 \pm 770.35 \mathrm{~mL})$. Forwards replaced less total fluid lost (63.64 $\pm 29.55 \%)$ than defenders (79.53 $\pm 38.71 \%)$, so they incurred a body mass deficit of $1.23 \pm 1.10 \%$, higher than defenders $(0.59 \pm 1.10 \%)$.

Table 3. Game time and fluid balance summary data in relation to playing position

\begin{tabular}{|c|c|c|c|c|c|c|}
\hline \multicolumn{2}{|c|}{ Defenders (n=5) } & \multicolumn{2}{|c|}{ Forwards (n=4) } & \multicolumn{2}{|c|}{$\begin{array}{c}\text { Effect } \\
\text { Size }\end{array}$} \\
\hline $\begin{array}{c}\text { Total game } \\
\text { time (min) }\end{array}$ & 49.78 & 3.93 & 50 & 3.13 & 0.899 & -0.07 \\
\hline $\begin{array}{c}\text { Body mass } \\
\text { loss (g) }\end{array}$ & 478.89 & 842.7 & 968.93 & 812.5 & 0.156 & 0.683 \\
\hline $\begin{array}{c}\text { Fluid intake } \\
\text { (mL) }\end{array}$ & 1493.33 & 770.3 & 1700.36 & 857.1 & 0.549 & 0.293 \\
\hline $\begin{array}{c}\text { Excreted } \\
\text { urine (mL) }\end{array}$ & 275.55 & 210.9 & 210 & 70.05 & 0.950 & 0.538 \\
\hline $\begin{array}{c}\text { Sweat loss } \\
\text { (mL) }\end{array}$ & 1695.56 & 673.7 & 2458.93 & 670.9 & 0.020 & -1.31 \\
\hline $\begin{array}{c}\text { Percentage of } \\
\text { sweat lost } \\
\text { replaced (\%) }\end{array}$ & 79.53 & 38.71 & 63.64 & 29.55 & 0.284 & 0.537 \\
\hline $\begin{array}{c}\text { Dehydration } \\
\text { (\% Body } \\
\text { weight lost) }\end{array}$ & 0.59 & 1.10 & 1.23 & 1.10 & 0.176 & 0.676 \\
\hline
\end{tabular}

* Significantly different in relation to playing position $(\mathrm{p} \leq 0.05)$

There is significant difference in the values of sweat loss in relation to player's position, as indicated by value $p$ $=0.020$ after applying the Kruskal-Wallis test. Effect size for this variable is -1.311 . However there are no significant differences in relation to fluid intake and dehydration of players.

Figure 1 shows that during the three studied matches mean fluid intake was similar in defenders and forwards. However mean sweat loss in forwards was always higher.

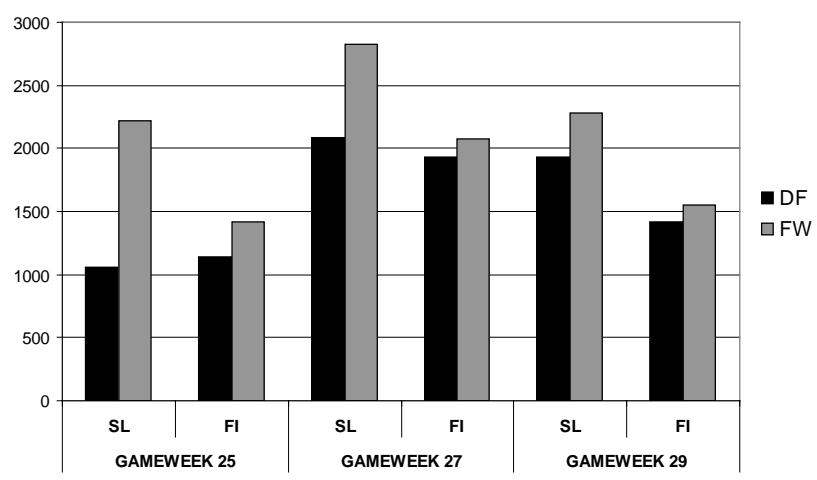

Figure 1. Sweat lost and fluid intake* in relation to playing position**

* SL: Sweat lost (mL); FI: Fluid intake (mL) **DF = Defenders; FW = Forwards

Mean game time was similar in defenders (49.78 \pm 3.93 min) and forwards (50 $\pm 3.13 \mathrm{~min})$. In addition, there is a positive relation between game time and level of dehydration (Spearman's Rho $=0.419, p=0.047$ ), so dehydration increases if game time increases.

\section{Discussion}

In this study we have assessed the hydration habits in elite field futsal players during official matches in relation to playing position. The results show that mean sweat lost in forwards is higher than defenders, resulting in higher levels of body weight lost.

Futsal played at highest level demands an excellent physical condition in players due to the physiological demands involved in competition (approximately 90\% of maximum heart rate) [35,36]. A high performance player needs an excellent ability to perform high-intensity intermittent exercise, and a rapid recovery during lowintensity activities. In this sense an adequate fluid replacement strategy is essential to avoid reduced performance [2,3,10,15,19,22,23,24]. Unlimited substitutions allow players to increase their chances of ingesting liquids while they are sitting on the bench. Barbero et al. [20] calculated that every field player (defender or forward) had 7.4 opportunities to hydrate per match.

Compared to studies with soccer players, fluid intake in our research (defenders 1493.33 $\pm 770.35 \mathrm{~mL}$ and forwards $1700.36 \pm 857.12 \mathrm{~mL}$ ) was higher than that calculated by Maughan et al. [26] and Shirreffs et al. [27], whose obtained a mean fluid intake of $971 \pm 303 \mathrm{~mL}$ and $972 \pm 335 \mathrm{~mL}$ respectively, after having analyzed soccer players during training sessions. In our study, defenders drunk less amount of liquid $(1493.33 \pm 770.35 \mathrm{~mL})$ than forwards $(1700.36 \pm 857.12 \mathrm{~mL})$. Mean fluid intake by players in our study exceeds results by Barbero et al. [20] in elite futsal players. Along these lines, another study with elite futsal players [37] obtained an average of 800 $\mathrm{mL}$ intake after a training session, less than the total fluid intake by our players. In other team sports, Schröder et al. [38] assessed fluid intake during training and competition in 55 elite basketball players, which mean result was 882 $\pm 486 \mathrm{~mL}$, less than that obtained in our study.

Despite a similar fluid intake, forwards finished matches with higher levels of dehydration $(1.23 \pm 1.10)$ than defenders $(0.59 \pm 1.10)$. There is significant difference in sweat lost in relation to playing position ( $p=$ 0.020 ; effect size $=-1.31$ ). Mean sweat lost was higher in forwards than in defenders.

This is in accordance with ACSM's Position Stand [15], which tells of the difficulty in giving a universal recommendation that adequately supplies for the needs of players due to the high variability of results obtained, even among members of the same team. In this context, various publications recommend pay attention to environmental conditions, intensity of effort or fluid intake to explain sweat losses and dehydration [9,10,15,23,29].

The environmental conditions in which the matches were played were similar $\left(22-26^{\circ} \mathrm{C} \quad 32-42,33 \% \quad \mathrm{RH}\right)$ because they were played in the same sports hall, which has cooling system.

Game time was similar in defenders and forwards $(49.78 \pm 3.93$ and $50 \pm 3.13 \mathrm{~min})$, so to identify physical demands of players in our research, we must study their playing position. Tactics characteristics of each position involving different values of distance or intensity of effort, for instance, between defenders and forwards [30,31,32].

In a study of elite futsal players, defenders covered similar distances to forwards (6185.52 $\pm 171.35 \mathrm{~m}$ versus $6885.06 \pm 996.41 \mathrm{~m}$ ), but duration of high intensity efforts 
was lower in defenders ( $13.5 \pm 2.5 \mathrm{~s}$ versus $55.5 \pm 12.5 \mathrm{~s})$, associating this data with lower-intensity efforts [32].

At the end of the games, players incurred a mean body mass deficit of $0.59 \pm 1.10 \%$ in defenders and $1.23 \pm 1.10$ in forwards. These values are not associated with a reduction in performance $[8,10,15,23]$. Due to the characteristics of futsal, it is recommended not to exceed $2 \%$ of body weight lost, as dehydration is associated with decreased aerobic performance and increased cardiac work [10,15,16,23], it also affecting motor sensory reactions such as reaction time and perceptual discrimination [23,24].

In similar researches, Barbero et al. [20] Hamouti et al. [37] and Martins et al. [34] studied the level of dehydration in futsal players. The study of Barbero et al. [20] assessed 13 elite futsal players, where mean percentage weight loss after three official matches was 1.1 $\pm 0.9 \%$, lower than forwards but higher than defenders of our research.

Hamouti et al. [37] obtained $1.2 \pm 0.3 \%$ body weight lost in elite futsal players after a training session. The mean weight loss rate is similar than that obtained by forwards in our study $(1.23 \pm 1.10 \%)$. Dehydration in defenders was lower $(0.59 \pm 1.10 \%)$.

The study conducted by Martins et al. [34] in futsal players show values of $0.43 \pm 0.41 \%$ weight loss after assessing 6 players (15-18 years) in training session. These results are lower than those obtained from the players in our study (defenders $0.59 \pm 1.10 \%$ and forwards $1.23 \pm 1.10 \%)$.

Regarding other team sports, in an investigation of percentage of weight loss in basketball players, Broad et al. [1] finds mean results were $1 \%$, similar to those obtained in forwards our study $(1.23 \pm 1.10 \%)$. Similar to this, Maughan et al. [26] found a mean $1.59 \pm 0.61 \%$ weight lost in soccer players during training. Also during a training session with soccer players, Shirreffs et al. [27] results were $1.62 \%$. In both publications [26,27], percentage of weight lost, was higher than in our study (DF $0.59 \pm 1.10 \%$ and FW $1.23 \pm 1.10 \%$ ).

Even defenders and forwards mean dehydration shows that fluid intake was enough to avoid reduced performance during official games.

\section{Conclusions}

Independently of playing position, fluid intake in these elite players was enough to offset losses caused by sweat. In a team sport like futsal, hydration status can be well maintained with regular substitutions and correct fluid intake. The results recommend monitoring player's body weight changes to estimate their sweat lost. If necessary, the coach can customize fluid replacement programs for each player, and not exclusively taking into account playing position or game time.

\section{Acknowledgement}

We thank players, coaching and managers from ElPozo Murcia Fútbol Sala for their participation and collaboration in this study.

\section{References}

[1] Broad, E. M., Burke, L.M., Cox, G.R., Heeley, P., Riley, M. (1996). Body weight changes and voluntary fluid intakes during training and competition sessions in team sports. International Journal of Sport Nutrition and Exercise Metabolism, 6, 307-320.

[2] Murray, R. (1996). Dehydration, hyperthermia, and athletes: science and practice. Journal of Athletic Trainning 31(3), 248-252.

[3] Burke, L.M. (1997). Fluid balance during team sports. Journal of Sports Science, 15(3), 287-295.

[4] Cox, G.R., Broad, E.M., Riley, M.D., Burke, L.M. (2002). Body mass changes and voluntary fluid intakes of elite level water polo players and swimmers. Journal of Science and Medicine in Sport, 5(3), 183-193.

[5] Maughan, R. J., Gleeson, M. (2004). The Biochemical Bases of Sports Performance. Oxford: Oxford University Press.

[6] Roses, J.M., Pujol, P. (2006). Hidratación y Ejercicio Físico. Apunts de Medicina del Deporte, 150, 70-77.

[7] Guyton, A.C. (1983). Fisiología Humana. México D.F.: Interamericana.

[8] Earle, R.W., Baechle, T.R. (2004). NSCA's Esentials of Personal Training. Champaign, IL: Human Kinetics.

[9] López-Román, J., Martínez, A. B., Luque, A., Villegas, J. A. (2008). Estudio comparativo de diferentes procedimentos de hidratación durante un ejercicio de larga duración. Archivos de Medicina del Deporte, 25(123), 435-444.

[10] Palacios, N., Franco, L., Manonelles, P., Manuz, B., Villegas, J.A. (2008). Consenso sobre bebidas para el deportista. Composición y pautas de reposición de líquidos. Archivos de Medicina del Deporte, 126(25), 245-258.

[11] Sawka M.N., Gonzalez R.R., Young A.J., Muza S.R., Pandolf K.B., Latzka W.A. et al. (1988). Polycythemia and hydration: Effects on thermoregulation and blood volume during exerciseheat stress. American Journal of Physiology, 255, 456-463.

[12] González-Alonso, J., Coyle, E.F. (1998) Efectos fisiológicos de la deshidratación. ¿Por qué los deportistas deben ingerir líquidos durante el ejercicio en el calor?. Apunts Educación Física y Deportes, 54, 46-52.

[13] Cheuvront, S.N., Carter, R., Sawka, M.N. (2003). Fluid balance and endurance exercise performance. Current Sports Medicine Reports, 2, 202-208.

[14] Coyle, E.F. (2004). Fluid and fuel intake during exercise. Journal of Sports Sciences, 22, 39-55.

[15] Sawka, M.N., Burke, L.M., Eichner, E.R., Maughan, R.J., Montain, S.J., Stachenfeld, N.S. (2007). Exercise and fluid replacement. Medicine and Science in Sports and Exercise, 39(2), 377-390.

[16] Wilmore, J.H., Costill, D.L. (2007). Physiology of Sport and Exercise. Champaign, IL: Human Kinetics.

[17] Stearns, R.L., Casa, D.J., López, R.M., McDermott, B.P., Ganio, M.S., Decher, N.R. et al. (2009). Influence of hydration status on pacing during trail running in the hear. Journal of Strength and Condition Research, 23(9), 2533-2541.

[18] Maughan, R.J., Shirrefs, S.M., Leiper, J.B. (2007). Errors in the estimation of hydration status from changes in body mass. Journal of Sports Sciences, 25(7), 797-804.

[19] Murray, R. (2007). Hydration and physical performance. Journal of the American College of Nutrition, 26(5Suppl), 542S-548S.

[20] Barbero, J.C., Castagna, C., Granda, J. (2006). Deshidratación y reposición hídrica en fútbol sala. Efectos de un programa de intervención sobre la pérdida de líquidos durante competición. Motricidad. European Journal of Human Movement, 17, 97-110.

[21] Harvey, G, Meir, R, Brooks, L, Holloway, K. (2008). The use of body mass changes as a practical measure of dehydration in team sports. Journal of Sports Science and Medicine, 11(6): 600-603.

[22] Manore, M.M., Meyer, N.L., Thompson, J. (2008). Sport Nutrition for Health and Performance. Champaign, IL: Human Kinetics.

[23] Casa, D. J., Clarkson, P.M., Roberts, W.O. (2005). American College of Sports Medicine roundtable on hydration and physical activity: consensus statements. Current Sports Medicine Reports, 4, 115-127.

[24] Montain, S.J. (2008). Hydration recommendations for sport. Current Sports and Medicine Report, 7(4), 187-192.

[25] American College of Sports Medicine (2007). ACSM Position Stand on Exercise and Fluid Replacement. Medicine Science and Sports Exercise, 39(2), 377-390. 
[26] Maughan, R.J., Merson, S.J., Broad, N.P., Shirreffs, S.M. (2004) Fluid and electroyte intake and loss in elite soccer players during training. International Journal of Sport Nutrition and Exercise Metabolism, 14(3), 333-346.

[27] Shirreffs, S. M., Aragon-Vargas, L.F., Chamorro, M., Maughan, R.J., Serratosa, L. Zachwieja, J.J. (2005). The sweating response of elite professional soccer players to training in the heat. International Journal of Sports Medicine, 26, 90-95.

[28] Martarelli, D., Ugoccioni, F., Stauffacher, F., Spataro, A., Cocchioni, M., Pompei, P. (2009). Assessment of body fluid balance and voluntary drinking in ultimate players during a match. Journal of Sports Medicine and Physical Fitness, 49(3), 265-271.

[29] Batchelder, B.C., Krause, B.A., Seegmiller, J.G., Starkey, C.A. (2010= Gastrointestinal temperature increases and hypohydration exists after collegiate men's ice hockey participation. Journal of Strength and Condition Research, 24(1), 68-73.

[30] MacLeod, H., Sunderland, C. (2009). Fluid balance and hydration habits of elite male field hockey players during consecutive international matches. Journal of Strength and Condition Research, 23(4), 1245-1251.

[31] Aragón-Vargas, L.F., Moncada-Jiménez, J., Hernández-Elizondo, J., Barrenechea, A., Monge-Alvarado, M. (2009). Evaluation of pre-game hydration status, heat stress, and fluid balance during professional soccer competition in the heat. European Journal of Sport Science, 9(5), 269-276.
[32] Hernández, J. (2001). Análisis de los parámetros espacio y tiempo en el fútbol sala. La distancia recorrida, el ritmo y dirección del desplazamiento del jugador durante un encuentro de competición. Apunts: Educación Física y Deportes, 65, 32-44.

[33] Norton, K., Whittinghan, N., Carter, L., Kerr, D., Gore, C., y Marfell-Jones, M (1996). Measurement techniques in anthropometry. In: K. Norton y T. Olds (Eds.), Antropométrica. Sydney: Editorial UNSW.

[34] Martins, M., Aparecida, J., Kleverson, J., Works, R.H., Wagner, R Bohn, J.H., Coppi, A. (2007). The corporal dehydration of amateur athletes of futsal. Revista Brasileira de Prescriçâo $e$ Fisiologia do Exercício, 1(5), 24-36.

[35] Barbero, J.C., Soto, V.M., Barbero, V., Granda-Vera, J. (2008). Match analysis and heart rate of futsal players during competition. Journal of Sports Science and Medicine, 126(1): 63-73.

[36] Castagna, C., D’Ottavio, S., Granda-Vera, J., Barbero, J.C. (2009). Match demands of proffesional futsal: a case study. Journal of Science and Medicine in Sport, 12(4): 490-494.

[37] Hamouti, N., Estévez, E., Del Coso, J., Mora, R. (2007). Fluid balance and sweat sodium concentration in elite indoor team sport players during training. Presented at $12^{\text {th }}$ Annual Congress of the ECSS, 11-14 July 2007, Jyvâskylâ, Finland.

[38] Schröder, H., Navarro, E., Mora, H., Seco, J., Torregrosa, J.M., Tramullas, A. (2004). Dietary habits and fluid intake of a group of elite Spanish basketball players: a need for professional advice? European Journal of Sport Science, 4(2), 1-15. 